\title{
Dietary composition and nutrient content of the New Nordic Diet
}

\author{
Charlotte Mithril ${ }^{1, *}+$, Lars Ove Dragsted ${ }^{1}$, Claus Meyer ${ }^{2}$, Inge Tetens ${ }^{3}$, \\ Anja Biltoft-Jensen ${ }^{3}$ and Arne Astrup ${ }^{1}$ \\ 'Department of Human Nutrition, Faculty of Science, University of Copenhagen, Frederiksberg, \\ Denmark: ${ }^{2}$ Meyers Madhus, Copenhagen, Denmark: ${ }^{3}$ Division of Nutrition, National Food Institute, \\ Technical University of Denmark, Søborg, Denmark
}

Submitted 23 January 2012: Final revision received 1 August 2012: Accepted 23 August 2012: First published online 22 October 2012

\begin{abstract}
Objective: To describe the dietary composition of the New Nordic Diet (NND) and to compare it with the Nordic Nutrition Recommendations (NNR)/Danish Food-based Dietary Guidelines (DFDG) and with the average Danish diet.

Design: Dietary components with clear health-promoting properties included in the DFDG were included in the NND in amounts at least equivalent to those prescribed by the DFDG. The quantities of the other dietary components in the NND were based on scientific arguments for their potential health-promoting properties together with considerations of acceptability, toxicological concerns, availability and the environment. Calculations were conducted for quantifying the dietary and nutrient composition of the NND.

Setting: Denmark.

Subjects: None.

Results: The NND is characterized by a high content of fruits and vegetables (especially berries, cabbages, root vegetables and legumes), fresh herbs, potatoes, plants and mushrooms from the wild countryside, whole grains, nuts, fish and shellfish, seaweed, free-range livestock (including pigs and poultry) and game. Overall, the average daily intakes of macro- and micronutrients in the NND meet the NNR with small adjustments based on evidence of their health-promoting properties. Conclusions: The NND is a prototype regional diet that takes palatability, health, food culture and the environment into consideration. Regionally appropriate healthy diets could be created on similar principles anywhere in the world.
\end{abstract}

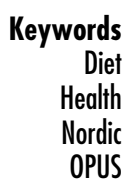

The major determinants of the burden of disease today are diet-related $^{(1,2)}$. In Denmark, as in the rest of the world, the prevalence of overweight and obesity in both children and adults has increased dramatically over the last 60 years ${ }^{(3,4)}$. Obesity increases the risk of a wide range of serious medical complications, including CVD, insulin resistance, type 2 diabetes, gallbladder disease, osteoarthritis, asthma and several cancers ${ }^{(5)}$. Ensuring that the population eats a healthy diet therefore remains a public health challenge. When making dietary recommendations it is important that the diet is palatable and attractive to the consumer ${ }^{(6)}$, and it has been suggested that tailoring the diet to regional conditions is also of importance ${ }^{(7)}$.

The Danish research project OPUS was established to investigate whether it is possible to develop a healthy New Nordic Diet (NND) that is palatable, environmentally

† Correspondence address: Madkulturen, Maglegårdsvej 12, 4000 Roskilde, Denmark. friendly and based largely on foods originating from the Nordic region. The overall aim of OPUS is to create 'Optimal well-being, development and health for Danish children through a healthy New Nordic Diet'.

The principles and guidelines of the NND are described in a previous paper ${ }^{(8)}$. In summary, the following principles were crucial in the development of the NND: health, gastronomic potential, Nordic identity, and sustainability. These principles led to the formulation of three fundamental guidelines as the basis of the NND as compared with the current average Danish diet: (i) more calories from plant foods and fewer from meat; (ii) more foods from the sea and lakes; and (iii) more foods from the wild countryside.

The objective of the present paper is to describe the dietary composition of the NND. A further objective is to compare the dietary composition of the NND with the Nordic Nutrition Recommendations (NNR)/Danish Food-based Dietary Guidelines (DFDG) and the average Danish diet. 


\section{Method}

OPUS is a Danish project and two intervention studies within the project are currently being carried out in Denmark (one in overweight adults and one in healthy schoolchildren), so food selection for the NND in this context is based on the Danish market and food culture, with reference to average dietary patterns in the Danish population. The overall principles, guidelines and dietary components can, however, easily be translated and applied to any country in the world. In order to justify the term 'New Nordic Diet', it is implicit that it should be possible to apply both the selection of foods and the nutrient contents directly in the Nordic or Northern European regions with minimal adjustments.

Each dietary component is chosen because of its presumed health-promoting potential, its distinct Nordic identity, its gastronomic potential, and because it can be produced in the Nordic region with consideration for the environment. Dietary components with evident healthpromoting properties included in the DFDG (e.g. fruits, vegetables, potatoes, whole grains, nuts, fish and shellfish) are included in the NND in at least the same amount as in the $\operatorname{DFDG}^{(9)}$. The recommended intakes of the other dietary components of the NND (e.g. fresh herbs, plants and mushrooms from the wild countryside, seaweed, meat and game) are based on scientific arguments for their potential health-promoting properties together with considerations of acceptability, toxicological concern, availability and environmental sustainability.

Availability and local food culture have also been considered in the selection of dietary components. We included dietary components that are available in the Nordic region in abundance and which are - or could become - easily available in all localities with only reasonable exertions made in regard to gathering, distribution, marketing, shopping, etc. The challenges regarding the general availability of the dietary components of the NND are a part of the work currently being done in OPUS and will not be further elaborated in the present paper.

Dietary calculations were conducted using the software GIES system version $1 \cdot 000 \mathrm{~d}$ and the Danish Food Composition Databank version 7 (National Food Institute, Technical University of Denmark, Søborg, Denmark; www.Foodcomp.dk) to quantify the dietary components and nutrient composition of the NND. The NND was designed to follow the NNR 2004 guidelines with respect to the overall macro- and micronutrient composition. Small adjustments were made when evidence for their health-promoting properties made this appropriate. For example, the NND aims to increase the intake of whole grains, as the evidence suggests that a high intake is associated with a reduction in the risk of several diseases $^{(10)}$; and the amount of protein in the NND is at the high end of the recommended range, because recent studies suggest that increased protein intake (20-25\% of energy (E\%)) may have a positive effect on the regulation of body weight, prevent diabetes and have a mild blood pressure-lowering effect ${ }^{(11-13)}$. It is important to bear in mind that the NND is not a weight reduction diet, but is an everyday diet developed for normal-weight people.

\section{Results}

\section{Dietary components in the New Nordic Diet}

Table 1 illustrates the suggested average daily intakes of the dietary components in the NND compared with the

Table 1 Overview of the average daily content of the dietary components in the New Nordic Diet (NND) in relation to the Danish Foodbased Dietary Guidelines (DFDG) ${ }^{(9)}$ and the average daily content in the Danish population ${ }^{(14)}$ (A Biltoft-Jensen, unpublished results)

\begin{tabular}{|c|c|c|c|}
\hline Dietary component & $\begin{array}{l}\text { Average content in } \\
\text { the NND }(\mathrm{g} / \mathrm{d})\end{array}$ & $\begin{array}{l}\text { Recommended intake } \\
\text { in the DFDG }(\mathrm{g} / \mathrm{d})\end{array}$ & $\begin{array}{l}\text { Average content in the } \\
\text { Danish population }(\mathrm{g} / \mathrm{d})\end{array}$ \\
\hline Fruit and vegetables & $\begin{array}{c}\text { Fruit: }>300 \\
\text { Vegetables: }>400\end{array}$ & $\begin{array}{c}\text { Fruit: } 300 \\
\text { Vegetables: } 300\end{array}$ & $\begin{array}{c}\text { Fruit: } 240 \\
\text { Vegetables: } 181\end{array}$ \\
\hline \multicolumn{4}{|l|}{ Including } \\
\hline Berries & $50-100$ & - & 5 \\
\hline Cabbages & $>29$ & - & 9 \\
\hline Root vegetables & $>150$ & - & 38 \\
\hline Legumes & $>30$ & - & 7 \\
\hline Fresh herbs & As much as possible & - & $<1$ \\
\hline Potatoes & $>140$ & $>140$ & 106 \\
\hline $\begin{array}{l}\text { Plants and mushrooms from } \\
\text { the wild countryside }\end{array}$ & 5 & - & $<1$ \\
\hline Whole grains & $>75$ & 75 & 36 \\
\hline Nuts & $>30$ & 30 & 1 \\
\hline Fish and shellfish & $>43$ & $29-43$ & 22 \\
\hline Seaweed & 5 & - & $<1$ \\
\hline $\begin{array}{l}\text { Free-range livestock (including } \\
\text { pigs and poultry) }\end{array}$ & $85-100$ & 100 & 143 \\
\hline \multicolumn{4}{|l|}{ Including } \\
\hline Game & $>4$ & - & $<1$ \\
\hline
\end{tabular}

All figures are based on the energy-adjusted intake (per 10 MJ) of all persons aged 4-75 years. 
DFDG recommended intakes ${ }^{(9)}$ and the average daily intakes in the Danish population ${ }^{(14)}$ (A Biltoft-Jensen, unpublished results). The quantification of each dietary component should not be seen as the definite amount but rather as a guiding average amount. The figures are average daily intake over a period of time, such as a week, and not necessarily eaten each day in the specific amount. For some dietary components (e.g. fruits and vegetables, potatoes, whole grains, nuts, fish and shellfish, game) the figures are average minimum amounts, while for others (e.g. plants and mushrooms from the wild countryside, seaweed and free-range livestock) the figures are more exact but still average amounts over time, e.g. a week. All figures are calculated and expressed per $10 \mathrm{MJ}$.

In the following each of the dietary components are elaborated and compared with the DFDG and the average daily intake in the Danish population ${ }^{(\mathcal{O}, 14)}$ (A Biltoft-Jensen, unpublished results). The reasoning behind the selection of the various dietary components is published in a previous paper $^{(8)}$.

\section{Fruits and vegetables}

The mean intake of fruit (including berries) and vegetables (including cabbages, root vegetables and legumes) in the average Danish adult population is just over $400 \mathrm{~g} / \mathrm{d}$, although the recommended intake is $600 \mathrm{~g} / \mathrm{d}$ for adults and children over 10 years $^{(9,14)}$ (A Biltoft-Jensen, unpublished results; Table 1). Studies have shown that with an increasing intake of fruits or vegetables there is a proportional decrease in the risk of $\mathrm{CVD}^{(15,16)}$, overweight and obesity ${ }^{(17)}$ and probably of certain cancers ${ }^{(18,19)}$. Fruit and vegetables therefore play an important role in the NND and the targeted intake was set to $700 \mathrm{~g} / \mathrm{d}$ (Table 1).

Specific fruits and vegetables were designated as more identifiable with the Nordic regions: berries, cabbages, root vegetables and legumes. These were selected because of their potential health-promoting properties, clear Nordic identity and environmentally sustainable production. Berries are a popular fruit; they are found in abundance in the wild and in season are freely accessible to the public. Berries are a good source for vitamins, minerals and dietary fibre, and they contain considerable amounts of polyphenols, especially anthocyanins ${ }^{(20,21)}$. The intake of berries in the NND is $50-100 \mathrm{~g} / \mathrm{d}$ as opposed to the mean intake in the Danish population of only $5 \mathrm{~g} / \mathrm{d}$ (Table 1 ). Cabbages and root vegetables can be a part of everyday meals all year around, and the intake in the NND is set at approximately 29 and $150 \mathrm{~g} / \mathrm{d}$, respectively, compared with the current average mean intake in the Danish population of 9 and $38 \mathrm{~g} / \mathrm{d}$, respectively (Table 1 ). Root vegetables are rich sources of dietary fibre, vitamins (especially A, B and C vitamins) and minerals (especially $\mathrm{Ca}$ and $\mathrm{Fe}$ in beetroot), but they have not been extensively explored for nonnutritive components of possible importance to health. In contrast, several studies indicate that cabbages may have specific health-promoting properties, e.g. as a prophylactic for cancer, above the general health benefits obtained from eating fruits and vegetables ${ }^{(22-26)}$. Cabbages have a high content of vitamin $\mathrm{K}$, antioxidants, dietary fibre, folate, and of several carotenoids and glucosinolates that are not found in other foods. The increased intake of legumes in the NND is designed to increase the amount of protein obtained from plant sources in order to reduce pressure on the environment. The amount of legumes in the NND is $30 \mathrm{~g} / \mathrm{d}$, while the mean intake in the Danish population today is $7 \mathrm{~g} / \mathrm{d}$ (Table 1). Some legumes are also sources of phyto-oestrogens which may be involved in protection against $\mathrm{CVD}^{(27)}$.

\section{Fresh herbs}

In the Middle Ages fresh herbs played a major role in the Danish kitchen, but their use has decreased significantly over time. In recent decades exotic dried spices have partially taken their place ${ }^{(28,29)}$. The current intake of fresh herbs in the Danish population is almost non-existent (less than $1 \mathrm{~g} / \mathrm{d}$; A Biltoft-Jensen, unpublished results; Table 1). In analogy to the current more abundantly used Mediterranean herbs such as thyme and oregano, the traditional Nordic herbs such as dill, parsley and chives are rich sources of aromatic terpenoids and of phytochemicals that may have health-promoting properties ${ }^{(30)}$. Fresh herbs are rich in vitamins and minerals, particularly vitamin $\mathrm{C}$ and Fe. The intake of fresh herbs in the NND was set as high as possible in order to exploit their gastronomic properties and potential health benefits. There are no official recommendations for intake of fresh herbs today.

\section{Potatoes}

Consumption of potatoes has fallen steadily since the introduction of rice and pasta to the Nordic countries and the average intake in the Danish population is now $106 \mathrm{~g} / \mathrm{d}$ (A Biltoft-Jensen, unpublished results; Table 1). Potatoes are an important source of dietary fibre, vitamins $\mathrm{B}_{6}$ and $\mathrm{C}$, folate, Fe, K and Mg in the Danish diet ${ }^{(14)}$ and it has been recommended that the average daily intake of potatoes should be increased to a minimum of $140 \mathrm{~g}$ (DFDG; Table 1). In addition, potatoes are among the foods that have the least negative environmental impact ${ }^{(31)}$. The intake of potatoes in the NND follows the DFDG of a minimum average daily intake of $140 \mathrm{~g}$ (Table 1). It should be emphasized that in this context potato in the form of crisps, chips, French fries, etc. is excluded.

\section{Plants and mushrooms from the wild countryside}

At present the Danish population eats practically no plants and mushrooms from the wild countryside (less than $1 \mathrm{~g} / \mathrm{d}$; Table 1). These foods have both health-promoting and gastronomic potential ${ }^{(8)}$ and intake in the NND is therefore increased to $5 \mathrm{~g} / \mathrm{d}$ (Table 1 ). However, wild plants have a high content of bioactive components, some of which can be toxic in large quantities. The daily intake of $5 \mathrm{~g}$ of edible 
wild plants and mushrooms in the NND corresponds, even for children, to a maximum intake of any one constituent of below $30 \mathrm{mg} / \mathrm{kg}$ body weight per $\mathrm{d}$. This should give rise to no concerns regarding toxicology for the plants included in the $\mathrm{NND}^{(32)}$.

\section{Whole grains}

There is strong evidence that whole grains have a healthpromoting potential ${ }^{(10)}$ and the DFDG recommend an average intake of $75 \mathrm{~g} / \mathrm{d}$ (Table 1 ). Studies have shown a significant inverse association between intake of whole grains and risk of $\mathrm{CVD}^{(33,34)}$, type 2 diabetes ${ }^{(35)}$, cancer $^{(36)}$, and weight gain or risk of obesity ${ }^{(37)}$. The average intake in the Danish population is only $36 \mathrm{~g} / \mathrm{d}$, i.e. less than half the recommended amount (Table 1 ). The quantity of whole grains in the NND is a minimum of $75 \mathrm{~g} / \mathrm{d}$ (Table 1 ).

\section{Nuts}

Nuts have a documented health-promoting potential and an intake of $30 \mathrm{~g} / \mathrm{d}$ is recommended by the DFDG (Table 1 ). There is some scientific evidence that consumption of nuts is associated with a reduced risk of $\mathrm{CVD}^{(38,39)}$ and weight gain and obesity ${ }^{(40)}$. The health-promoting effects of nuts are probably due to their high content of MUFA, protein, dietary fibre, vitamins (especially vitamin E, but also B vitamins, particularly folic acid, niacin and $\mathrm{B}_{6}$ ) and minerals (particularly $\mathrm{Mg}$ and $\mathrm{K})^{(41)}$. Nuts have a lot of flavour and can be used as an alternative to sweets and to make salads, muesli and bread more appetizing. The average intake of nuts is currently about $1 \mathrm{~g} / \mathrm{d}$ in the Danish population (Table 1). The amount in the NND is at least $30 \mathrm{~g} / \mathrm{d}$ (Table 1). Only unsalted, non-oiled nuts are included.

\section{Fish and shellfish}

Fish and shellfish have a significant health-promoting potential and regular fish consumption is recommended ${ }^{(42)}$. The DFDG recommends intakes of 200 to $300 \mathrm{~g} /$ week, corresponding to an average intake of $29-43 \mathrm{~g} / \mathrm{d}^{(9)}$ (Table 1 ). Fatty fish contain high amounts of $n-3$ fatty acids, which have been shown to improve child brain development and help prevent CVD and nervous disorders in adults ${ }^{(43)}$. In addition, fish and shellfish have a high content of valuable vitamins and minerals, including vitamin $\mathrm{D}$, iodine and Se, which are difficult to find naturally in other foods. High-quality fish are abundant in the Nordic region, but a large part of the catch is exported. Different species of fish contain different amounts of vitamins, minerals and fatty acids. Intake should therefore be alternated between fatty and lean species and between different origins (Atlantic, Baltic, freshwater) in order to get the full health benefits while minimizing risks due to pollution with organohalides, As and heavy metals. The average intake in the Danish population is $22 \mathrm{~g} / \mathrm{d}-$ far below the recommended intake (Table 1 ). The amount included in the NND is $43 \mathrm{~g} / \mathrm{d}$ corresponding to an intake of $300 \mathrm{~g} /$ week (Table 1).

\section{Seaweed}

Seaweed is an overlooked source of nutrition in the Western world and the intake in the Danish population is close to zero (Table 1), although is was previously part of the poor man's diet all along the Nordic coastline ${ }^{(44)}$. Seaweed has a high content of essential minerals, protein, dietary fibre, vitamins (A, B, C, E) and essential fatty acids ${ }^{(44)}$. It also has a range of bioactive compounds, which may be beneficial in relation to CVD and have a potential antiviral and anticancer effect ${ }^{(45)}$. The composition of seaweeds varies greatly with species and region origin, and these can give rise to some concerns, including risks from relatively high contents of iodine. The majority of seaweeds in the Nordic region are edible and non-toxic, but the NND recommendations are set at $5 \mathrm{~g} / \mathrm{d}$ (fresh weight) because of the high iodine content in certain species (Table 1).

\section{Free-range livestock (including pigs and poultry) and game}

Consumption of meat has almost doubled in the Nordic countries over the past 50 years and today the average intake in the Danish population is $143 \mathrm{~g} / \mathrm{d}^{(14,46)}$ (Table 1). There are no official quantitative guidelines for intake of meat in Denmark, but an average intake of $100 \mathrm{~g} / \mathrm{d}$ per adult person is considered adequate ${ }^{(47)}$. Meat is among the least environmentally friendly foods; the NND seeks to decrease the intake of meat and replace it with more environmentally friendly protein sources such as fish and shellfish, legumes and nuts. The recommendation for dietary protein in Denmark is currently 10-20 E\%, which corresponds to $0 \cdot 8$ to $1.6 \mathrm{~g} / \mathrm{kg}$ body weight ${ }^{(42)}$. The amount of energy from protein in the NND is set at a minimum of $1 \mathrm{~g} / \mathrm{kg}$ body weight, which can easily be achieved by a meat intake of 85-100 g/d combined with other sources of protein (e.g. fish and shellfish, wholegrain, vegetables, nuts, milk, cheese and eggs). Women of childbearing age must ensure sufficient Fe in their diet and should therefore have an intake of meat at the high end of the recommendation. The high content of fruit and vegetables in the NND gives a high intake of vitamin $\mathrm{C}$, which stimulates Fe absorption in the body, and a greater proportion of the Fe intake in the NND is therefore expected to be absorbed, thereby helping further to compensate the Fe loss in these women.

The NND focuses on meat from free-range animals, for reasons of sustainability and gastronomy, and potentially also for health. Studies have shown that meat from animals that graze has a healthier fatty acid composition, with less saturated fat and more polyunsaturated fat, than meat from animals reared indoors without access to grass $^{(48,49)}$. In addition, the NND has a higher content of game. Game is unique in gastronomy, because the animals have fed on plants that reflect the specific climate and landscapes of the region. The intake of game in the NND is $4 \mathrm{~g} / \mathrm{d}$, as opposed to the current intake in the Danish population of less than $1 \mathrm{~g} / \mathrm{d}$ (Table 1 ). 
Table 2 Overview of the average daily composition and intakes of protein, fat, carbohydrates and alcohol as a percentage of total energy intake (E\%) for the New Nordic Diet (NND), the recommended intake according to the Nordic Nutrition Recommendations (NNR) ${ }^{(42)}$ and the average composition of the diet in the Danish population ${ }^{(14,42)}$

\begin{tabular}{lccr}
\hline & $\begin{array}{c}\text { Average composition } \\
\text { of the NND }\end{array}$ & $\begin{array}{c}\text { Recommended } \\
\text { intake from NNR }\end{array}$ & $\begin{array}{c}\text { Average composition of the diet } \\
\text { in the Danish population }\end{array}$ \\
\hline Protein (E\%) & 17 & 15 & 14 \\
Fat (E\%) & 32 & 30 & 33 \\
SFA (E\%) & 10 & $\leq 10$ & 14 \\
MUFA (E\%) & 13 & $10-15$ & 12 \\
PUFA (E\%) & 8 & $5-10$ & 5 \\
Carbohydrates (E\%) & 51 & 55 & 48 \\
Dietary fibre (g) & 41 & $25-35$ & 23 \\
Refined sugars (E\%) & 4 & $\leq 10$ & 11 \\
Alcohol (E\%) & 1 & $\leq 5$ & 6 \\
\hline
\end{tabular}

All figures are for groups of individuals 10-75 years of age, with a heterogeneous age and sex distribution (for alcohol, 18-75 years of age).

Table 3 Overview of the average daily composition and intakes of nutrients in the New Nordic Diet (NND) in relation to the intake recommended by the Nordic Nutrition Recommendations (NNR) ${ }^{(42)}$ and the average composition of the diet in the Danish population ${ }^{(4,42)}$

\begin{tabular}{lccc}
\hline Nutrient & $\begin{array}{c}\text { Average composition } \\
\text { of the NND }\end{array}$ & $\begin{array}{c}\text { Recommended intake } \\
\text { from NNR }\end{array}$ & $\begin{array}{c}\text { Average composition of the diet in } \\
\text { the Danish population }\end{array}$ \\
\hline Vitamin A (RE) & 1556 & 800 & $1148 \cdot 5$ \\
Vitamin D ( $\mu \mathrm{g})$ & 5 & 10 & $3 \cdot 3$ \\
Vitamin E $(\alpha-\mathrm{TE})$ & 15 & 9 & $7 \cdot 6$ \\
Thiamin $(\mathrm{mg})$ & $1 \cdot 8$ & $1 \cdot 2$ & $1 \cdot 4$ \\
Riboflavin $(\mathrm{mg})$ & $2 \cdot 1$ & $1 \cdot 4$ & $1 \cdot 8$ \\
Niacin $(\mathrm{NE})$ & 36 & 16 & 31 \\
Vitamin $\mathrm{B}_{6}(\mathrm{mg})$ & $2 \cdot 0$ & $1 \cdot 3$ & $1 \cdot 6$ \\
Folate $(\mu \mathrm{g})$ & 528 & 450 & 341 \\
Vitamin $\mathrm{B}_{12}(\mu \mathrm{g})$ & $7 \cdot 1$ & 2 & $5 \cdot 5$ \\
Vitamin C $(\mathrm{mg})$ & 266 & 1000 & 123 \\
Ca $(\mathrm{mg})$ & 1351 & 800 & 1226 \\
$\mathrm{P}(\mathrm{mg})$ & 1976 & $3 \cdot 5$ & 1559 \\
$\mathrm{~K}(\mathrm{~g})$ & $5 \cdot 1$ & 350 & $3 \cdot 6$ \\
Mg $(\mathrm{mg})$ & 476 & 16 & 365 \\
Fe $(\mathrm{mg})$ & 14 & 11 & $10 \cdot 8$ \\
$\mathrm{Zn}(\mathrm{mg})$ & 14 & 1 & $-1 \cdot 7$ \\
Cu $(\mathrm{mg})$ & $3 \cdot 5$ & 170 & 216 \\
lodine $(\mu \mathrm{g})$ & 590 & 40 & 46
\end{tabular}

RE, retinol equivalents; $\alpha$-TE, $\alpha$-tocopherol equivalents; NE, niacin equivalents.

All figures are based on the energy-adjusted intake per $10 \mathrm{MJ}$ for groups of individuals 10-75 years of age, with a heterogeneous age and sex distribution (for the NNR, 6-60 years of age). The values are adapted to the reference person requiring the highest dietary nutrient density.

Other dietary components

The intakes of other dietary components in the NND follow the DFDG, e.g. dairy products $(500 \mathrm{~g} / \mathrm{d}$ for milk, $25 \mathrm{~g} / \mathrm{d}$ for cheese), eggs $(25 \mathrm{~g} / \mathrm{d})$, beverages, sweets, etc ${ }^{(9)}$. We make no further elaboration on these dietary components here, as they do not differ from the DFDG.

\section{Nutritional content of the New Nordic Diet}

The following overview of the macro- and micronutrients in the NND was calculated from a full day's diet including the dietary components in Table 1, dairy products and eggs according to the recommended daily intake, $25 \mathrm{~g} / \mathrm{d}$ for butter/oil, $15 \mathrm{~g} / \mathrm{d}$ for sugar, and with a daily allowance of sweets, alcohol, etc. of $75 \mathrm{~g} / \mathrm{d}$ (Appendix). Some of the dietary components in the NND are missing in the nutritional databases and best estimates have been made for items such as fresh herbs, plants and mushrooms from the wild countryside and seaweed. The result should therefore not be regarded as definitive for the NND. Tables 2 and 3 present the average daily intakes of macro- and micronutrients in the NND compared with the recommended intake according to the NNR and the average daily intake in the Danish population ${ }^{(14,42)}$ (A Biltoft-Jensen, unpublished results). All figures are for groups of individuals 10-75 years of age (for alcohol the age group is $18-75$ years). The values in Table 3 are adapted for the reference person requiring the highest dietary nutrient density.

\section{Macronutrient distribution in the New Nordic Diet}

As shown in Table 2, the average diet of the Danish adult population provides $14 \mathrm{E} \%$ from protein, $33 \mathrm{E} \%$ from fat, $48 \mathrm{E} \%$ from carbohydrate and $6 \mathrm{E} \%$ from alcohol ${ }^{(15)}$. By comparison, the recommended energy distribution according to the NNR is $30 \mathrm{E} \%$ from fat, $55 \mathrm{E} \%$ from carbohydrate, $15 \mathrm{E} \%$ from protein and maximum $5 \mathrm{E} \%$ 
from alcohol ${ }^{(42)}$. The excess fat intake in the Danish population is primarily of SFA, where the content is $14 \mathrm{E} \%$ compared with the recommended level of maximum $10 \mathrm{E} \%$. The Danish population has an average intake of dietary fibre of $23 \mathrm{~g} / \mathrm{d}$ compared with the recommended intake of $25-35 \mathrm{~g} / \mathrm{d}$, and about $25 \%$ of adults in the Danish population consume more added sugars than the recommended maximum of $10 \mathrm{E} \%{ }^{(14)}$

The NND provides $17 \mathrm{E} \%$ from protein, $32 \mathrm{E} \%$ from fat, $51 \mathrm{E} \%$ from carbohydrate and $1 \mathrm{E} \%$ from alcohol. The quantity of SFA follows the recommendations of $10 \mathrm{E} \%$, and the intake of dietary fibre of $41 \mathrm{~g} / \mathrm{d}$ exceeds the recommendations. The intake of refined sugar in the NND is limited to $4 \mathrm{E} \%$.

The energy intake from fat is slightly higher in the NND compared with the recommended intake, but was accepted for the gastronomic properties. How this diet will affect body weight in overweight subjects remains to be tested.

\section{Micronutrient distribution in the New Nordic Diet}

The micronutrient content of the average Danish diet is generally sufficient as defined in the NNR, apart from a few exceptions (Table 3). The Danish diet contains abundant amounts of vitamin A, riboflavin, niacin, $\mathrm{B}_{12}$, vitamin $\mathrm{C}, \mathrm{Ca}, \mathrm{P}$ and iodine. The contents of vitamin $\mathrm{E}$, thiamin, vitamin $\mathrm{B}_{6}, \mathrm{~K}, \mathrm{Mg}, \mathrm{Zn}$ and Se are acceptable. The vitamin $\mathrm{D}$ content is too low in all age groups and the folate and Fe contents are insufficient for many females of fertile age.

The amount of all nutrients other than vitamin $\mathrm{D}$ and Fe is abundant in the NND (Table 3). The vitamin D content of the NND is $5 \mu \mathrm{g} / \mathrm{d}$ as opposed to $3 \mu \mathrm{g} / \mathrm{d}$ in the average Danish diet, while the Fe content of the NND is $14 \mathrm{mg} / \mathrm{d}$ as opposed to $11 \mathrm{mg} / \mathrm{d}$ in the average Danish diet (Table 3). Females of childbearing age might benefit from additional dietary Fe, so the NND recommends that they eat $100 \mathrm{~g}$ of meat daily. Like everyone else in Nordic countries, populations eating the NND need to ensure an appropriate intake of vitamin D-rich products, especially during the winter when sunlight is scarce and vitamin D synthesis limited. The NND has a relatively high content of iodine, due to the fortification of kitchen salt in Denmark with iodine and the relatively high content of iodine in milk because the animal feed is also fortified with iodine. The iodine content of Danish seaweeds is not known and we have therefore used data for species with the highest content of iodine in the calculations, estimating the worst-case scenario. The estimated upper level (UL) for iodine is $600 \mu \mathrm{g} / \mathrm{d}$ and the amount of iodine in the NND is acceptable $^{(42)}$. There is no figure for the content of salt in the NND, since the level of salt in the diet is very dependent on the amount added to food during cooking. The NND is not a specific low-salt diet, but is aimed at following the NNR with regard to the level of salt in the diet, which is a maximum of $5-6 \mathrm{~g} / \mathrm{d}^{(42)}$.

\section{Discussion}

Nordic foods have become gastronomically highly appreciated internationally, but as a Northern European food culture the Nordic regional diets have not been regarded as healthy. The low carbon footprint of locally produced foods makes them the more sustainable choice. The NND is an attempt to address all these aspects and to create a diet with all three characteristics, i.e. being tasty, healthy and sustainable $^{(8)}$. A diet based on Nordic foods and the NNR within the Swedish tradition has already been tested in a small human dietary study and results indicated considerable health potentials of this approach ${ }^{(50)}$. Another study on Nordic foods concluded that traditional healthy Nordic foods were found to be related to lower mortality among middle-aged Danes, in particular among men ${ }^{(51)}$. However, the principles governing a designed diet such as the NND are not easily translated into food choices and menus. For the NND, we suggest here choices of actual foods that are consistent with the guidelines for the NND and which at the same time are in general agreement with the NNR with respect to nutrient distribution. The composition of the NND deviates slightly from the NNR, most notably in the higher fibre intake due to the high fruit, vegetable, legume and whole grains content, and for some of these the level is above that recommended in the DFDG. There is evidence that these higher levels may potentially have a positive effect on health and there are no obvious contraindications. The increased intake of vitamin $\mathrm{C}$ and of non-haem $\mathrm{Fe}$ should lead to improved Fe status in women, and the high content of legumes and fish should balance out the relative decrease in protein intake from meat.

Precise nutrient composition of many of the dietary components included in the NND is missing from the food composition databases. The risk of errors in our calculations of the nutrient content of the NND should therefore be taken into consideration. Some of the more unusual constituents of the NND, such as wild plants and seaweeds, require careful examination of the risk of adverse effects. This will be examined in more detail elsewhere, but we already know that the iodine content is, conservatively calculated, in excess of the recommended UL for safety. This may be attributable to the limitations of the data available on the different seaweeds, leading to an exaggerated mean level of iodine in seaweeds in the estimations. The limitations of the food composition databases underline the gaps in our general knowledge of the safety and/or potential benefits of food components such as seaweeds and wild plants. Further research is needed in order to pave the way for safe and healthy use of these resources in dietary improvements.

The dietary components and suggested intake of each food in the current paper are not intended to be an unequivocal final answer, but rather as one of several possible suggestions for a Danish version of a healthy and sustainable regional diet. The dietary components have 
been used to develop a range of specific recipes for the OPUS intervention studies and selected recipes have recently been published in a Danish cookbook ${ }^{(52)}$. As we test the NND we should learn more about how to develop it further.

\section{Concluding remarks}

The NND is a prototype regional diet with concern for palatability, health, food culture and the environment. Similar regionally adapted diets could be created using these principles anywhere in the world. The principles can be used to create diets that respect the existing dietary guidelines using local produce and create recipes that are consistent with the local food culture and acceptable in the population. The effectuation of the NND in a free-living population and its possible health effects are currently being tested with an aim to provide proof of principle for the construction of a healthy New Nordic Diet.

\section{Acknowledgements}

Sources of funding: The present study is a part of the OPUS project. OPUS is an acronym of the Danish title of the project 'Optimal well-being, development and health for Danish children through a healthy New Nordic Diet'. The OPUS Centre is supported by grant from the Nordea Foundation, Denmark, and is independent of all commercial interests. Conflict of interest: C. Mithril, L.O.D., I.T. and A.B.-J. have no conflicts of interest. C. Meyer is an owner of restaurants, food companies and a cooking school, and the New Nordic Cuisine is a theme in most of C. Meyer's companies. A.A. is an advisor, an advisory board member or a scientific board member for the Communications and Scientific Advisory Board of The Global Dairy Platform (Chicago, IL, USA), the Kraft Health \& Wellness Advisory Council (Glenview, IL, USA), the Beer Knowledge Institute (Amsterdam, The Netherlands), the Pathway Genomics Corporation (La Jolla, CA, USA) and Jennie Craig (Carlsbad, CA, USA); and receives honoraria as a speaker and research funding from a wide range of Danish and international concerns. Authors' contributions: The draft paper was elaborated by C. Mithril based on an OPUS report on the NND, which was developed by C. Mithril in close collaboration with C. Meyer, E. Blauert, M.K. Holt, L.O.D. and A.A. and with dietary input from I.T. and A.B.-J. L.O.D., I.T. and A.B.-J. helped C. Mithril shape the draft paper into its final form which was then approved with minor corrections by the other co-authors. Acknowledgements: The authors thank the Advisory Boards assisting OPUS Work Package 1 and the participants at the OPUS congress held in June 2009 in Copenhagen for their valuable input and help in the development of the NND. They also greatly thank dietitian Karin Hess Ygil from DTU Food for making the dietary calculations of the NND.

\section{References}

1. Ezzati M, Lopez AD, Rodgers A et al. (2002) The comparative risk assessment collaborating group. Selected major risk factors and global and regional burden of disease. Lancet 360, 1347-1360.

2. World Health Organization (2009) Global Health Risks: Mortality and Burden of Disease Attributable to Selected Major Risks. Geneva: WHO.

3. Bendixen H, Holst C, Sørensen TIA et al. (2004) Major increase in prevalence of overweight and obesity between 1987 and 2001 among Danish adults. Obes Res 12, 1464-1472.

4. Pearson S, Olsen LW, Hansen B et al. (2005) Increase in overweight and obesity amongst Copenhagen schoolchildren, 1947-2003. Ugeskr Lager 167, 158-162.

5. Haslam DW \& James PT (2005) Obesity. Lancet 366, 1197-1209.

6. Sørensen LB, Møller P, Flint A et al. (2003) Effect of sensory perception of foods on appetite and food intake: a review of studies on humans. Int J Obes Relat Metab Disord 27, 1152-1166.

7. Bere E \& Brug J (2009) Towards health-promoting and environmentally friendly regional diets - a Nordic example. Public Health Nutr 12, 91-96.

8. Mithril C, Dragsted LO, Meyer C et al. (2012) Guidelines for the New Nordic Diet. Public Health Nutr 15, 1941-1947.

9. Astrup A, Andersen NL, Stender S et al. (2005) Kostrådene 2005 (National Food Based Dietary Guidelines 2005). Copenhagen: Danish Nutrition Council \& Danish Institute for Food and Veterinary Research.

10. Mejborn H, Biltoft-Jensen A, Trolle E et al. (2008) FuldkornDefinition og vidensgrundlag for anbefaling af fuldkornsindtag i Danmark (Wholegrain - Definition and Scientific Background for Recommendations of Wholegrain Intake in Denmark). Søborg: Department of Nutrition, National Food Institute, Technical University of Denmark.

11. Paddon-Jones D, Westman E, Mattes RD et al. (2008) Protein, weight management, and satiety. Am J Clin Nutr 87, issue 5, 1558S-1561S.

12. Due A, Toubro S, Stender S et al. (2005) The effect of diets high in protein or carbohydrate on inflammatory markers in overweight subjects. Diabetes Obes Metab 7, 223-229.

13. Larsen TM, Dalskov SM, van Baak M et al. (2010) Diets with high or low protein content and glycemic index for weight-loss maintenance. N Engl J Med 363, 2102-2113.

14. Pedersen AN, Fagt S, Groth MV et al. (2010) Dietary habits in Denmark, 2003-2008. Søborg: Department of Nutrition, National Food Institute, Technical University of Denmark.

15. He FJ, Nowson CA \& MacGregor GA (2006) Fruit and vegetable consumption and stroke: meta-analysis of cohort studies. Lancet 367, 320-326.

16. He FJ, Nowson CA, Lucas $M$ et al. (2007) Increased consumption of fruit and vegetables is related to a reduced risk of coronary heart disease: meta-analysis of cohort studies. J Hum Hypertens 21, 717-728.

17. Duijnhoven FJB, Bueno-De-Mesquita HB, Ferrari $\mathrm{P}$ et al. (2009) Fruit, vegetables, and colorectal cancer risk: the European Prospective Investigation into Cancer and Nutrition. Am J Clin Nutr 89, 1441-1452.

18. World Cancer Research Fund/American Institute for Cancer Research (2007) Food, Nutrition, Physical Activity and the Prevention of Cancer: A Global Perspective. Washington, DC: AICR Press.

19. Basu A, Rhone M \& Lyons TJ (2010) Berries: emerging impact on cardiovascular health. Nutr Rev 68, 168-177.

20. Battino M, Beekwilder J, Denoyes-Rothan B et al. (2009) Bioactive compounds in berries relevant to human health. Nutr Rev 67, Suppl. 1, S145-S150. 
21. Bere E (2007) Wild berries: a good source of omega-3. Eur J Clin Nutr 61, 431-433.

22. London SJ, Yuan JM, Chung FL et al. (2000) Isothiocyanates, glutathione $S$-transferase M1 and T1 polymorphisms, and lung-cancer risk: a prospective study of men in Shanghai, China. Lancet 356, 724-729.

23. Wang LI, Giovannucci EL, Hunter D et al. (2004) Dietary intake of cruciferous vegetables, glutathione $S$-transferase (GST) polymorphisms and lung cancer risk in a Caucasian population. Cancer Causes Control 15, 977-985.

24. Fowke JH, Chung FL, Jin F et al. (2003) Urinary isothiocyanate levels, brassica, and human breast cancer. Cancer Res 63, 3980-3986.

25. Ambrosone CB, McCann SE, Freudenheim JL et al. (2004) Breast cancer risk in premenopausal women is inversely associated with consumption of broccoli, a source of isothiocyanates, but is not modified by GST genotype. J Nutr 134, 1134-1138.

26. Kirsh VA, Peters U, Mayne ST et al. (2007) Prospective study of fruit and vegetable intake and risk of prostate cancer. J Natl Cancer Inst 99, 1200-1209.

27. Bazzano LA, Thompson AM, Tees MT et al. (2011) Non-soy legume consumption lowers cholesterol levels: a meta-analysis of randomized controlled trials. Nutr Metab Cardiovasc Dis 21, 94-103.

28. Boyhus E (1996) Grønsager - en køkkenhistorie. Copenhagen: Gyldendalske Boghandel, Nordisk Forlag A/S.

29. Skaarup B \& Jacobsen H (1999) Middelaldermad. Copenhagen: Nyt Nordisk Forlag A/S.

30. Cornwell T, Cohick W \& Raskin I (2004) Dietary phytoestrogens and health. Phytochemistry 65, 995-1016.

31. Saxe H, Jensen RB \& Petersen ML (2006) Fødevarers miljøeffekter (Environmental Effects of Food). Copenhagen: Environmental Assessment Institute.

32. Kroes R, Renwick AG, Cheeseman M et al. (2004) Structurebased thresholds of toxicologigal concern (TTG): guidance for application to substances present at low levels in the diet. Food Chem Toxicol 42, 65-83.

33. Kelly SA, Summerbell CD, Brynes A et al. (2007) Wholegrain cereals for coronary heart disease. Cochrane Database Syst Rev issue 2, CD005051.

34. Pereira MA, O'Reilly E, Augustsson K et al. (2004) Dietary fiber and risk of coronary heart disease. Arch Intern Med 164, 370-376.

35. Liese AD, Roach AK, Sparks KC et al. (2003) Whole-grain intake and insulin sensitivity: the Insulin Resistance Atherosclerosis Study. Am J Clin Nutr 78, 965-971.

36. Egeberg R, Olsen A, Loft $S$ et al. (2010) Intake of wholegrain products and risk of colorectal cancers in the
Diet, Cancer and Health cohort study. Br J Cancer 103 730-734

37. Howarth NC, Saltzman E \& Roberts SB (2001) Dietary fiber and weight regulation. Nutr Rev 59, 129-139.

38. Richardson DP, Astrup A, Cocaul A et al. (2009) The nutritional and health benefits of almonds: a healthy food choice. Food Sci Technol Bull Funct Foods 6, issue 4, $41-50$.

39. Sabaté J, Oda K \& Ros E (2010) Nut consumption and blood lipid levels: a pooled analysis of 25 intervention trials. Arch Intern Med 170, 821-827.

40. Sabaté J \& Ang Y (2009) Nuts and health outcomes: new epidemiologic evidence. Am J Clin Nutr 89, 1643-1648.

41. Sabaté J, Ros E \& Salas-Salvadó J (2006) Nuts: nutrition and health outcomes. Preface. Br J Nutr 96, Suppl. 2, S1-S2.

42. Nordic Council of Ministers (2004) Nordic Nutrition Recommendations 2004. Integrating Nutrition and Physical Activity, 4th ed. Copenhagen: Nordic Council of Ministers.

43. Andersen JK, Büchert A, Koch B et al. (2003) Helhedssyn på fisk og fiskevarer (General View of Fish and Fish Products). Søborg: Danish Veterinary and Food Administration.

44. Mouritsen OG (2009) Tang (Seaweed). Copenhagen: Nyt Nordisk Forlag Arnold Busck.

45. Cooksley VG (2007) Seaweed. New York: Harry N. Abrams, Inc.

46. Groth MV \& Fagt S (2001) Trends in dietary habits in Denmark and Sweden since the 1960's. Ugeskr Laeger 163, 425-429.

47. Ovesen L (2002) Kødindtaget i Danmark og dets betydning for ernoering og sundhed (Meat Intake in Denmark and its Effect on Nutrition and Health). Copenhagen: Ministry of Food, Agriculture and Fisheries.

48. Scollan N, Hocquette JF, Nuernberg K et al. (2006) Innovations in beef production systems that enhance the nutritional and health value of beef and their relationship with meat quality. Meat Sci $\mathbf{7 4}, 17-33$.

49. Cordain L, Watkins BA, Florant GL et al. (2002) Fatty acid analysis of wild ruminant tissues: evolutionary implications for reducing diet-related chronic disease. Eur J Clin Nutr 56, 181-191.

50. Adamsson V, Reumark A, Fredriksson IB et al. (2011) Effects of a healthy Nordic diet on cardiovascular risk factors in hypercholesterolaemic subjects: a randomized controlled trial (NORDIET). J Intern Med 269, 150-159.

51. Olsen A, Egeberg R, Halkjær J et al. (2011) Healthy aspects of the Nordic diet are related to lower total mortality. J Nutr 141, 639-644.

52. Meyer C \& Astrup A (2011) Ny Nordisk Hverdagsmad (New Nordic Diet). Copenhagen: Strandberg Publishing. 
Appendix

Overview of the dietary composition of an example of a full day's diet in the New Nordic Diet (NND) used for calculating the nutritional content of the NND

\begin{tabular}{|c|c|}
\hline Dietary component & Average content in the NND $(\mathrm{g} / \mathrm{d})$ \\
\hline Fruits & 350 in total \\
\hline Fruit assorted (excluding juice) & 250 \\
\hline Berries & 75 \\
\hline Apple juice & 50 \\
\hline Vegetables & 450 in total \\
\hline Cabbages & 30 \\
\hline Root vegetables & 150 \\
\hline Legumes, fresh & 20 \\
\hline Legumes, dried & $10($ dry weight $)=25$ (boiled $)$ \\
\hline Other vegetables & 240 \\
\hline Fresh herbs & 1 \\
\hline Potatoes & 175 \\
\hline Plants and mushrooms from the wild countryside & 5 \\
\hline Wholegrain bread/cereals & 275 \\
\hline Nuts and seeds & 30 \\
\hline Fish and shellfish & 43 \\
\hline Seaweed & 5 \\
\hline Free-range livestock (including pigs and poultry) & 100 in total \\
\hline Low-fat meat & 76 \\
\hline High-fat meat & 20 \\
\hline Game & 4 \\
\hline Milk and dairy products & 525 in total \\
\hline Low-fat milk & 450 \\
\hline High-fat milk & 30 \\
\hline Cream ( $9 \%$ fat) & 20 \\
\hline Low-fat cheese & 12 \\
\hline High-fat cheese & 13 \\
\hline Butter & 10 \\
\hline Rapeseed oil & 15 \\
\hline Eggs & 25 \\
\hline Sugar & 15 \\
\hline Beverages & 1000 in total \\
\hline Water & 600 \\
\hline Coffee/tea & 400 \\
\hline Daily allowance for e.g. & 75 in total \\
\hline Soft drinks & 28 \\
\hline Alcohol & 28 \\
\hline Candy and ice cream & 4 \\
\hline Cake & 6 \\
\hline Chips & 1 \\
\hline Fast food & 8 \\
\hline
\end{tabular}

All figures are based on the energy-adjusted intake (per 10 MJ) of all persons aged 4-75 years. 